Archive for

Organic Chemistry

Arkivoc 2020, part v, 17-27

\title{
The synthesis of 7,9-dimethoxy-3-propyl-3,4-dihydro-1H-benzo[g] isochromene- 1,5,10-trione: A potential monomer for the synthesis of the natural product xylindein
}

\author{
Md. Firoj Hossain, Andreas Lemmerer," and Charles B. de Koning* \\ Molecular Sciences Institute, School of Chemistry, University of the Witwatersrand, PO Wits 2050, \\ Johannesburg, South Africa \\ Email: Charles.deKoning@wits.ac.za
}

Received 07-24-2020

Accepted 08-22-2020

Published on line $09-09-2020$

\section{Abstract}

A novel synthesis of a 3-propyl-substituted-benzo[g]isochromene quinone, a potential monomer of the natural product xylindein, was accomplished in 9 steps (overall yield of 8.2\%) from 2,4dimethoxybenzaldehyde. Key steps included the use of a cross-metathesis reaction in which ethyl-3-allyl-4(benzyloxy)-1,6,8-trimethoxy-2-naphthoate was converted into ethyl-4-(benzyloxy)-1,6,8-trimethoxy-3-(4oxopent-2-enyl)-2-naphthoate as a mixture of (E)- and (Z)-isomers. Following an oxa-Michael addition reaction, a racemic mixture of the desired product, 5-(benzyloxy)-7,9,10-trimethoxy-3-(2-oxopropyl)-3,4dihydro- $1 \mathrm{H}$-benzo[g]isochromen-1-one, the basic xylindein lactone skeleton, was obtained.
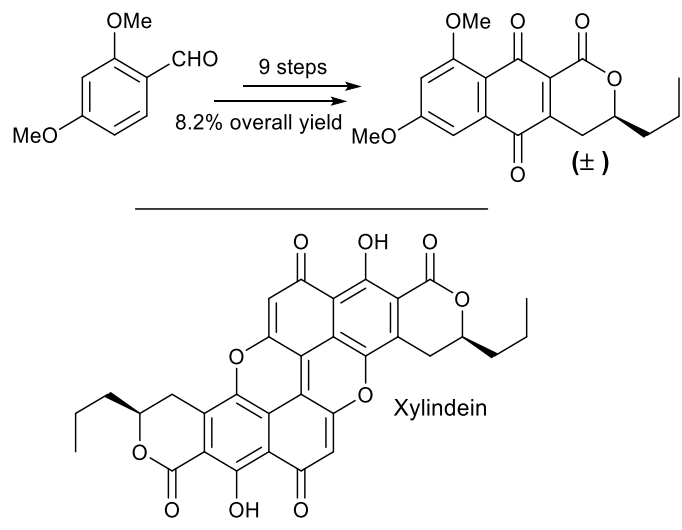

Keywords: Xylindein, benzo[g]isochromene quinone, cross-metathesis, oxa-Michael addition 


\section{Introduction}

Anhydrofusarubin lactone (1) and 5-methoxy-3,4-dehydrosemixanthomegnin (2) are examples of lactonecontaining aromatic compounds. Both compounds belong to an expanding class of quinone-containing compounds (Figure 1). ${ }^{1}$ Anhydrofusarubin lactone $(\mathbf{1})^{2}$ is found in several fungi such as Nectria haematococca and Fusarium solani, while 5-methoxy-3,4-dehydrosemixanthomegnin $(\mathbf{2})^{3}$ has been isolated from Paepalanthus latipes Silveira (family Eriocaulaceae). Related aromatic compounds, but not quinones, are paepalantine (3) and 9-O-methyl paepalantine (4), as well as the dimer of paepalantine (5), have been isolated from a related Eriocaulaceae species Paepalanthus bromelioides ${ }^{4}$ and Paepalanthus vellozioides. ${ }^{5}$ A more complex, related dimeric-fused lactone-containing aromatic compound possessing a stereogenic center at C-3 is xylindein (6), produced by fungi from genus Chlorociboria aeruginosa (Figure 2). This pigment is known for the green staining of wood. The artificial coloring of wood with $C$. aeruginosa is a patented process, and oak staining using this procedure is used in decorative woodworking such as Tunbridge ware. ${ }^{6}$<smiles>[R]Oc1c2c(c(O)c3c(=O)oc(C)cc13)C(=O)C=C(OC)C2=O</smiles>

$1, \mathrm{R}=\mathrm{H}$, anhydrofusarubin lactone

2, $\mathrm{R}=\mathrm{Me}, 5$-methoxy-3,4-dehydrosemixanthomegnin<smiles>[R]Oc1cc(OC)cc2c(O)c3c(=O)oc(C)cc3c(O)c12</smiles>

3, $\mathrm{R}=\mathrm{H}$, paepalantine

4, $\mathrm{R}=\mathrm{Me}, 9-\mathrm{O}-$ methylpaepalantine<smiles></smiles>

Figure 1. Examples of naturally occurring lactone-containing aromatic compounds.

The structure of xylindein was elucidated, independently, by Todd et al. ${ }^{7}$ and by Edwards and Kale. ${ }^{8}$ More recently, the absolute configuration and tautomeric structure of xylindein have been described. ${ }^{9}$ An interesting potential application of xylindein is that it has been investigated for use as a sustainable organic agent for optical- and electronic-property applications. ${ }^{10}$

Two research groups have attempted the synthesis of xylindein. Giles et al. ${ }^{11}$ and Green et al. ${ }^{12}$ have postulated that the possible biosynthetic precursor to xylindein was the lactone-containing quinone $\mathbf{7}$ (Figure 2). While the racemic quinone $\mathbf{7}$ could be synthesized in very poor yields, the authors concluded that "new synthetic strategies to the elusive $\delta$-lactone 7 will have to be sought." ${ }^{12}$

Gill and Donner ${ }^{13}$ postulated that the naphthol $\mathbf{8}$, or even the lactone deficient aromatic compound $\mathbf{9}$, might be better building blocks for the formation of xylindein. ${ }^{14}$ The use of these building blocks was postulated on the basis of previous literature. In this research, the extended quinone, xylaphin, was prepared from a pyran-containing aromatic compound rather than a lactone precursor. Naphthol $\mathbf{8}$ was synthesized by Gill using Staunton-Weinreb annulation methodology, while 9 was synthesized by Donner using the Diels-Alder 
reaction as a key step. None of these approaches, however, allowed for the synthesis of the target compound, xylindein.

In our laboratories, we have explored the synthesis of lactone-containing aromatic compounds. This has resulted in the synthesis of 5-methoxy-3,4-dehydrosemixanthomegnin (2) and 9-O-methylpaepalantine (5), a methoxy derivative of paepalantine (3). ${ }^{15}$ Hence, we believed that we would be able to synthesize the quinone-containing lactone 7. In principle, dehydration of 7 should result in the formation of xylindein.

In this paper, we disclose novel methodology we have developed for the racemic synthesis of 7,9dimethoxy-3-propyl-3,4-dihydro-1H-benzo[g]isochromenene-1,5,10-trione (10), a potential monomer en route to the synthesis of xylindein (6).
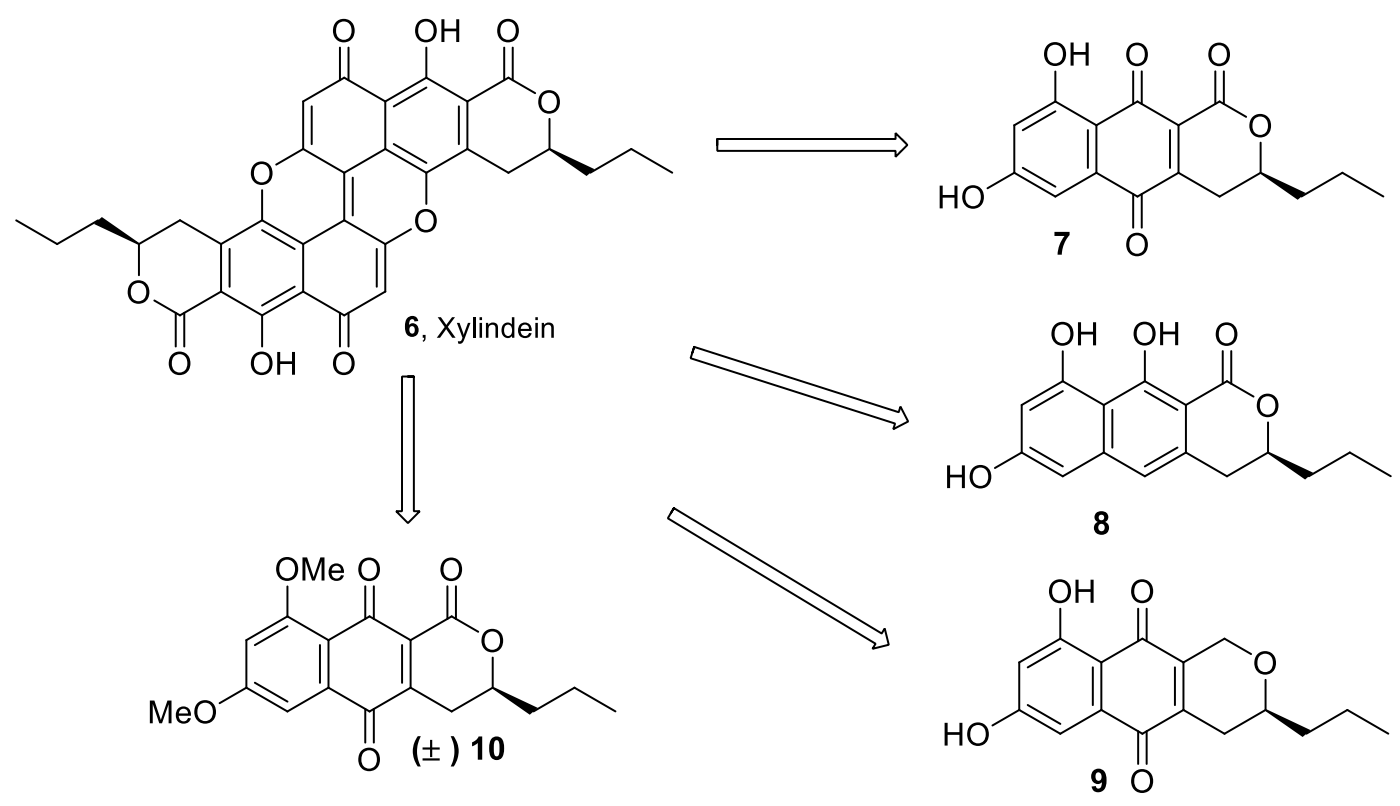

Figure 2. Postulated monomeric aromatic building blocks for the assembly of xylindein.

\section{Results and Discussion}

We have previously described the synthesis of the trioxygenated naphthalene $11^{16 a}$ as well as related PIFAmediated methodology ${ }^{16 \mathrm{~b}}$ for the synthesis of the correctly substituted 1,4,6,8-tetraoxygenated naphthalene nucleus 12 of the xylindein monomer. We envisaged that the ester at C-2 and the allyl substituent at C-3 of the naphthalene 12 would allow for possible synthetic routes for the synthesis of the desired isochromenone moiety of 10.

2,4-Dimethoxybenzaldehyde was treated under Stobbe reaction conditions with diethyl succinate in the presence of $t$ - $\mathrm{BuOH}$ and $t$-BuOK to afford the intermediate half-ester, which was subjected to $\mathrm{Ac}_{2} \mathrm{O}$ and $\mathrm{NaOAc}$ to afford the required naphthalene, ethyl 4-acetoxy-6,8-dimethoxynaphthalene-2-carboxylate, along with a minor product, $t$-butyl-4-acetoxy-6,8-dimethoxy-2-naphthoate (see experimental). Following a further synthetic step described in the literature, ${ }^{16 a}$ the desired trioxygenated naphthalene $\mathbf{1 1}$ containing a $C$-allyl substituent was furnished in good yield. Using the PIFA-mediated Kozlowski conditions ${ }^{17}$ allowed for the introduction of the required methoxy substituent at C-1 of $\mathbf{1 1}$ to afford 12 in good yield of 75\% (Scheme 1). It 
now remained to protect the naphthol $\mathbf{1 2}$ with an appropriate protecting group that would allow for selective removal at a later stage of the synthesis. O-Benzylation of $\mathbf{1 2}$ afforded $\mathbf{1 3}$ in excellent yield.
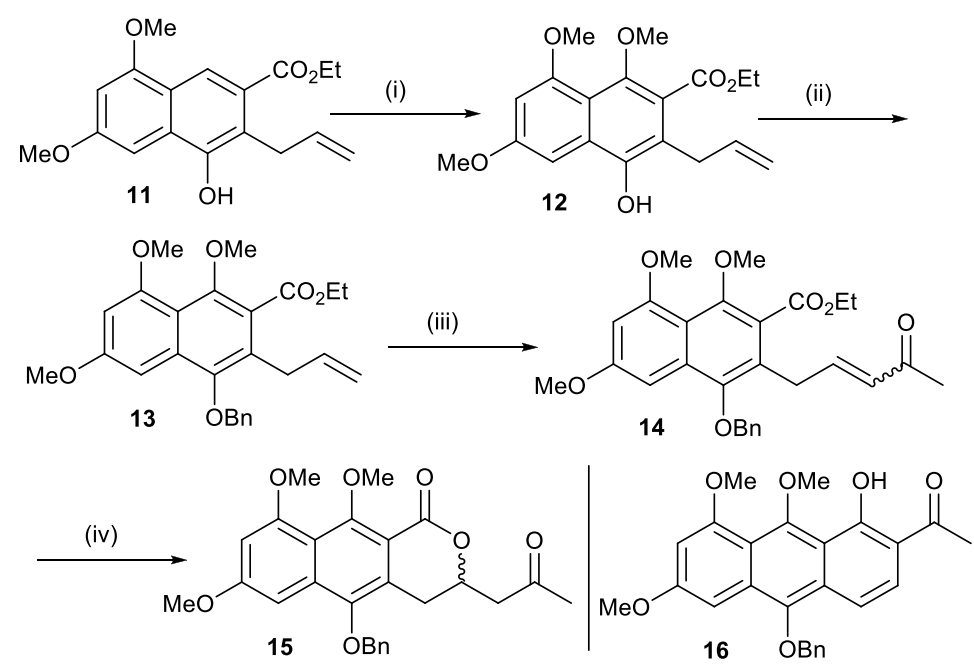

Scheme 1. Reagents and Conditions: (i) (a) PIFA, $\mathrm{MeOH}, \mathrm{rt}, 15 \mathrm{~min}$, (b) ${ }^{\mathrm{t}} \mathrm{BuOK}, \mathrm{EtOH}, 20 \mathrm{~min}, 75 \%$; (ii) $\mathrm{PhCH} \mathrm{Br}^{\mathrm{Br}}$, $\mathrm{K}_{2} \mathrm{CO}_{3}$, acetone, 95\%; (iii) Grubbs II catalyst, methyl vinyl ketone, $\mathrm{CH}_{2} \mathrm{Cl}_{2}$, reflux, 15 min, 70\%; (iv) $\mathrm{BF}_{3} \cdot \mathrm{OEt}_{2}, 0$ ${ }^{\circ} \mathrm{C}, 64 \%$.

The next step in the synthesis was the construction of the appropriate 3-propyl-substituted chromanone ring via a cross metathesis reaction of $\mathbf{1 3}$ with methyl vinyl ketone in the presence of the Grubbs II catalyst. This resulted in the formation of the $\alpha, \beta$-unsaturated carbonyl compound $\mathbf{1 4}$ as a mixture of $(E)$ - and (Z)isomers. The Michael acceptor 14 was exposed to $\mathrm{BF}_{3} \cdot \mathrm{OEt}_{2}$ at $0{ }^{\circ} \mathrm{C}$ to give the desired isochromene-1-one 15 in good yield. Treatment of 14 with a $10 \%$ potassium hydroxide solution in a mixture of water and ethanol resulted in the formation of anthracene $\mathbf{1 6}$ in a poor yield of $20 \%{ }^{18}$

The next step required the removal of the ketone carbonyl of $\mathbf{1 5}$. The thioacetal $\mathbf{1 7}$ was readily formed by treatment of $\mathbf{1 5}$ with ethanedithiol under acidic conditions as shown in Scheme 2 (structure confirmed by Xray crystallography ${ }^{19}$ ), along with a minor product, which indicated that one of the methyl ether groups was no longer present, and had resulted in the formation of naphthol 17a. Our basis for suggesting that the 10hydroxynaphthalene 17a had formed was that a signal for the hydroxyl $\mathrm{H}$ was observed at $\delta 12.99$ in the ${ }^{1} \mathrm{H}$ NMR spectrum, indicating hydrogen bonding to the adjacent lactone carbonyl.

The conversion of the thioacetal $\mathbf{1 7}$ to liberate the propyl substituent was the next step. As the thioacetal 17 also contained an $O$-benzyl ether, we believed that reaction conditions could be manipulated to efficiently afford the trimethoxynaphthol, 5-hydroxy-7,9,10-trimethoxy-3-propyl-3,4-dihydro-1H-benzo[g]isochromen-1one that would facilitate the oxidation step to the required naphthoquinone 10. Thioacetal 17 was exposed to Raney nickel in refluxing ethanol for $72 \mathrm{~h}$. Much to our surprise, not only was the thioacetal no longer present, but the methoxy substituent at C-10 that we had previously introduced was no longer evident. As expected, however, under the reaction conditions, the $O$-benzyl substituent was no longer present, and the $\mathrm{C}-5$ naphthol, 5-hydroxy-7,9,-dimethoxy-3-propyl-3,4-dihydro-1H-benzo[g]isochromen-1-one (18) had formed. Evidence for this was that no hydrogen-bonded phenol was observed in the ${ }^{1} \mathrm{H}$ NMR spectrum of 18, and the proton at $\mathrm{C}-10$ of the ${ }^{1} \mathrm{H}$ NMR spectrum which appeared at $\delta 8.65$ seemed to be incorrect for the $\mathrm{C}-10$ naphthol. In fact, if the regioisomer, 10-hydroxy-7,9-dimethoxy-3-propyl-3,4-dihydro-1H-benzo[g]isochromen- 
1-one, had been formed, the ${ }^{1} \mathrm{H}$ NMR spectrum would show a more shielded singlet at about $\delta$ 7. This was corroborated by examining the ${ }^{1} \mathrm{H}$ NMR of a related product, 10-hydroxy-7,9-dimethoxy-3-methyl-1Hbenzo[g]isochromen-1-one, where the proton attached to $\mathrm{C}-5$ was observed at 6.92 in the ${ }^{1} \mathrm{H}$ NMR spectrum. ${ }^{20}$ Therefore, the isochromenone 18 containing a 5,7,9-trihydroxynaphthalene had been formed. The ${ }^{1} \mathrm{H}$ NMR spectrum showed one aromatic singlet at $\delta 8.65$, as well as two meta-coupled doublets at $\delta 6.93(1 \mathrm{H}$, d, J $1.9 \mathrm{~Hz}$ ) and $6.47(1 \mathrm{H}, \mathrm{d}, J 1.9 \mathrm{~Hz}$ ) while, in the $135 \mathrm{DEPT}$ spectrum, there were three aromatic C-H signals at $\delta 119.78,98.13$ and 91.5 . Further evidence for the formation of the naphthol 18 was obtained from HRMS (calcd. for $\mathrm{C}_{18} \mathrm{H}_{21} \mathrm{O}_{5}(\mathrm{M}+\mathrm{H})^{+} 317.1390$, found 317.1390). Undeterred by this result, we exposed the naphthol 18 to CAN which furnished the desired quinone 10 in good yield.
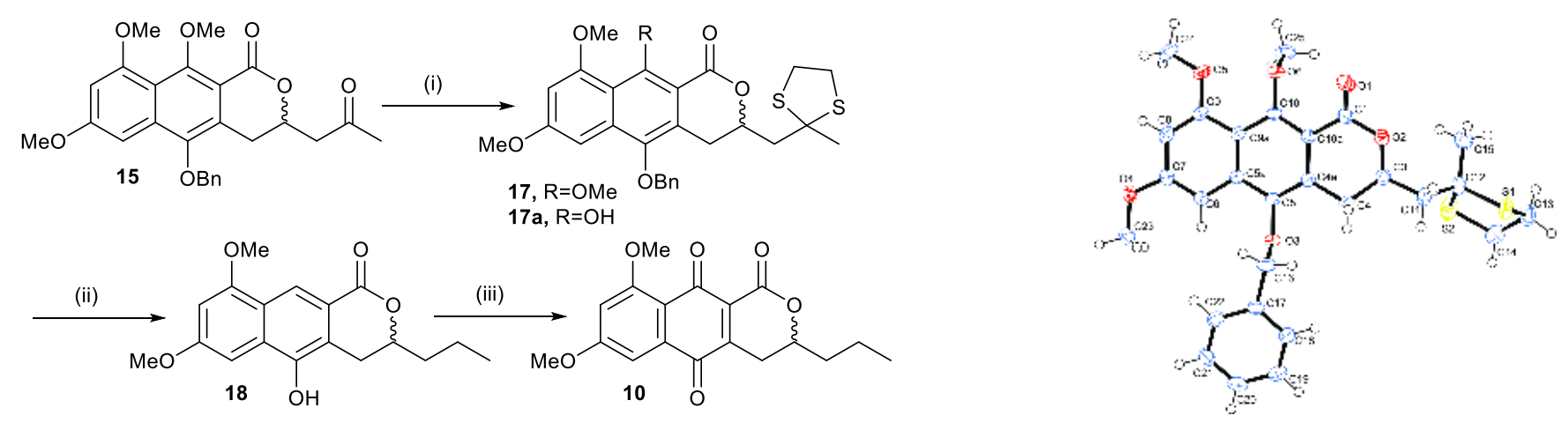

Scheme 2. Reagents and Conditions: (i) ethanedithiol, $\mathrm{p}-\mathrm{TsOH}$, toluene, reflux, $18 \mathrm{~h}, 70 \%$; (ii) Raney $\mathrm{Ni}$, EtOH, reflux, $72 \mathrm{~h}, 79 \%$; (iii) CAN, $\mathrm{MeCN}, 0^{\circ} \mathrm{C}, 30 \mathrm{~min}, 80 \%$.

\section{Conclusions}

Using 2,4-dimethoxybenzaldehyde as the starting material, we have been able to develop a novel synthesis of a 3-propyl-substituted benzo[g]isochromenone quinone, a potential monomer of the natural product xylindein, in 9 steps with an overall yield of $8.2 \%$. Currently, we are exploring the utilization of this quinone as the monomer unit for the assembly of xylindein. As the methoxy substituent at C-10 was unexpectedly lost in the conversion of $\mathbf{1 7}$ into 18, attempts are being made to conduct the same synthetic steps commencing with compound 13, lacking the methoxy substituent, however, at C-1.

\section{Experimental Section}

General. ${ }^{1} \mathrm{H}$ NMR and ${ }^{13} \mathrm{C}$ NMR spectra were recorded on a Bruker AVANCE 300 spectrometer. All chemical shift values are reported in parts per million (ppm) referenced against TMS which is given an assignment of zero ppm. Coupling constants ( $J$-values) are given in Hertz $(\mathrm{Hz})$. All mass spectroscopy data were collected on a Waters Acquity UPLC system coupled to a Waters HDMS G1 QTOF mass spectrometer. UPLC settings: Analytical column: BEH C18 $150 \times 2.1 \mathrm{~mm}$; Column temperature: $60{ }^{\circ} \mathrm{C}$; Mobile phase: $90 \%$ water $(0.1 \%$ formic acid): $5 \%$ acetonitrile; Flow rate: $0.4 \mathrm{~mL} / \mathrm{min}$. MS settings: Mode: VTOF; Ionisation: ESIPos and ESINeg; Scan range: 100-1000 Da; Scan speed: 0.1 second; Run time: 10 mins. Infrared spectra were recorded on a Bruker Tensor 27 standard system spectrometer with diamond ATR attachment. Macherey-Nagel Kieselgel 60 
(particle size $0.063-0.200 \mathrm{~mm}$ ) was used for conventional silica gel column chromatography with various EtOAc and hexane mixtures as the mobile phase. TLC was performed on aluminum-backed Macherey-Nagel Alugram Sil G/UV254 plates pre-coated with $0.25 \mathrm{~mm}$ silica gel 60. The Bruker D8 VENTURE PHOTON CMOS area detector diffractometer, equipped with a graphite monochromated Mo K $\alpha_{1}$ radiation (50 kV, $30 \mathrm{~mA}$ ), was used to collect all the intensity data. The program SAINT+, v. $6.02^{21}$ was used to reduce the data, and the program $S A D A B S$ was used to make corrections to the empirical absorptions. Space group assignments were made using $X P R E P^{21}$ on all compounds. In all cases, the structures were solved in the WinGX ${ }^{22}$ Suite of programs by direct methods using SHELXS $-97^{23}$ and refined using full-matrix least-squares/difference Fourier techniques on $F^{2}$ using SHELXL-97. ${ }^{23}$ All non-hydrogen atoms were refined anisotropically. All C-H hydrogen atoms were placed at idealized positions and refined as riding atoms with isotropic parameters 1.2 or 1.5 times those of the 'heavy' atoms to which they are attached. Diagrams and publication material were generated using ORTEP-3, ${ }^{24}$ and PLATON. ${ }^{25}$ Experimental details of the X-ray analyses are given for $t$-butyl-4acetoxy-6,8-dimethoxy-2-naphthoate in the experimental section and for 5-(benzyloxy)-7,9,10-trimethoxy-3(2-methyl-1,3-dithiolan-2-yl)methyl-3,4-dihydro-1H-benzo[g]isochromen-1-one (17) in the experimental section.

\section{Ethyl-4-acetoxy-6,8-dimethoxynaphthalene-2-carboxylate and $t$-butyl-4-acetoxy-6,8-dimethoxy-2-} naphthoate. To a solution of 2,4-dimethoxybenzaldehyde $(5.45 \mathrm{~g}, 32.8 \mathrm{mmol})$ and diethyl succinate $(8.18 \mathrm{~mL}$, $49.2 \mathrm{mmol}$ ) in dry ${ }^{\mathrm{t}} \mathrm{BuOH}(80 \mathrm{~mL})$, stirred under $\mathrm{N}_{2}$, was added ${ }^{\mathrm{t}} \mathrm{BuOK}(5.52 \mathrm{~g}, 49.2 \mathrm{mmol})$. The reaction mixture was heated under reflux for $2 \mathrm{~h}$ and then allowed to cool to rt, poured onto ice and made acidic to $\mathrm{pH} 3.0 \mathrm{with}$ conc. aqueous $\mathrm{HCl}$. The product precipitated before it was dissolved and extracted with ethyl acetate $(2 \times 100$ $\mathrm{mL}$ ). The combined extracts were dried with $\mathrm{MgSO}_{4}$, filtered through Celite, and the filtrate was concentrated in vacuo. The resultant oily residue and anhydrous $\mathrm{NaOAc}(6.72 \mathrm{~g}, 81.9 \mathrm{mmol})$ were dissolved in $\mathrm{Ac}_{2} \mathrm{O}(100 \mathrm{~mL})$ and refluxed for $3 \mathrm{~h}$ before being allowed to cool. The remaining $\mathrm{Ac}_{2} \mathrm{O}$ was removed in vacuo, $\mathrm{H}_{2} \mathrm{O}(100 \mathrm{~mL})$ was added, and the product was extracted with EtOAc $(3 \times 100 \mathrm{~mL})$. Drying of the combined EtOAc extracts $\left(\mathrm{MgSO}_{4}\right)$, followed by filtration through Celite, and removal of the solvent in vacuo, gave a brown semi-solid which was purified by silica gel column chromatography ( $28 \%$ ethyl acetate-hexane). Initially, a minor product, t-butyl-4-acetoxy-6,8-dimethoxy-2-naphthoate was eluted and subsequently obtained as a yellow crystalline solid (1.14 g, 10\%), mp 139-141 ${ }^{\circ} \mathrm{C}$. IR (solid, $\mathrm{v}_{\max } \mathrm{cm}^{-1}$ ): $1760,1702 .{ }^{1} \mathrm{H}$ NMR $\left(300 \mathrm{MHz}, \mathrm{CDCl}_{3}\right): \delta(\mathrm{ppm}) 8.74$ $(1 \mathrm{H}, \mathrm{d}, J$ 1.6), $7.74(1 \mathrm{H}, \mathrm{d}, J$ 1.6), $6.65(1 \mathrm{H}, \mathrm{d}, J 2.0), 6.52(1 \mathrm{H}, \mathrm{d}, J 2.0), 3.97(3 \mathrm{H}, \mathrm{s}), 3.91(3 \mathrm{H}, \mathrm{s}), 2.46(3 \mathrm{H}, \mathrm{s}), 1.62$ $(9 \mathrm{H}, \mathrm{s}) .{ }^{13} \mathrm{C}$ NMR $\left(75 \mathrm{MHz}, \mathrm{CDCl}_{3}\right): \delta$ (ppm) 169.3, 165.4, 160.8, 157.9, 145.4, 131.0, 126.1, 123.0, 122.3, 119.2, 98.5, 91.6, 81.1, 55.8, 55.4, 28.3 (× 3), 21.0. Crystal data for $t$-butyl-4-acetoxy-6,8-dimethoxy-2-naphthoate, assigned CCDC no. $1030315, \mathrm{C}_{19} \mathrm{H}_{22} \mathrm{O}_{6}: \mathrm{M}_{r} 346.37 \mathrm{~g}$. mol ${ }^{-1}$; crystal dimensions $(\mathrm{mm}) 0.40 \times 0.34 \times 0.23$; crystal system, monoclinic; space group, $C 2 / c$; unit cell dimensions and volume, $a=17.2795(11) \AA, b=9.8328(4) \AA, c$ $=22.8241(9) \AA, \alpha=90^{\circ}, \beta=104.799(2)^{\circ}, \gamma=90^{\circ}, V=3749.3(3) \AA^{3}, Z=8$; calculated density $r_{\text {calcd }}, 1.227 \mathrm{Mg} / \mathrm{m}^{3}$; linear absorption coefficient, $\mu=0.091 \mathrm{~mm}^{-1}$; radiation and wavelength, MoK $\alpha_{1}=0.71073 \AA$; temperature of measurement, $173(2) \mathrm{K}, 2 \theta_{\max } 28.00^{\circ} ; 24655$ reflections measured, 4512 unique reflections, 3293 observed reflections $[I>2 \sigma(I)] ; R_{\text {int }}=0.0402 ; R_{1}[I>2.0 \sigma(I)]=0.0539$, wR2 [all] $=0.1536$, GoF $=1.016$, refined on $F^{2}$; residual electron density, 0.456 and $-0.369 \mathrm{e}^{-3}$.

The major desired product, ethyl 4-acetoxy-6,8-dimethoxynaphthalene-2-carboxylate (8.10 g, 77\%) was obtained as a white solid. ${ }^{1} \mathrm{H}$ NMR $\left(300 \mathrm{MHz}, \mathrm{CDCl}_{3}\right): \delta_{\mathrm{H}}(\mathrm{ppm}) 8.79(1 \mathrm{H}, \mathrm{d}, J 1.1), 7.81(1 \mathrm{H}, \mathrm{d}, J 1.1), 6.66(1 \mathrm{H}$, $\mathrm{d}, J$ 1.9), $6.51\left(1 \mathrm{H}, \mathrm{d}, J\right.$ 1.9), $4.42(2 \mathrm{H}, \mathrm{q}, J \mathrm{~J} .1), 3.98(3 \mathrm{H}, \mathrm{s}), 3.91(3 \mathrm{H}, \mathrm{s}), 2.46(3 \mathrm{H}, \mathrm{s}), 1.42(3 \mathrm{H}, \mathrm{t}, J 7.1) .{ }^{13} \mathrm{C} \mathrm{NMR}$ $\left(75 \mathrm{MHz}, \mathrm{CDCl}_{3}\right): \delta_{\mathrm{C}}(\mathrm{ppm}) 169.3,166.3,161.0,157.9,145.4,133.2,124.4,123.4,122.2,119.1,98.6,91.7,61.0$, $55.8,55.4,20.9,14.4 .^{16 a}$ 
Ethyl-4-acetoxy-6,8-dimethoxynaphthalene-2-carboxylate was converted into ethyl-3-allyl-4-hydroxy-6,8dimethoxynaphthalene-2-carboxylate $\mathbf{1 1}$ in a reproducible yield of $75 \%$ using a known literature procedure. $^{15,16 a}$

Ethyl-3-allyl-4-hydroxy-1,6,8-trimethoxynaphthalene-2-naphthoate $\quad$ (12). Ethyl-3-allyl-4-hydroxy-6,8dimethoxynaphthalene-2-carboxylate 11 (6.02 g, $16.85 \mathrm{mmol})$ was dissolved in $\mathrm{MeOH}(100 \mathrm{~mL})$ in a roundbottomed flask. PIFA ( $9.4 \mathrm{~g}, 21.90 \mathrm{mmol})$ was added and the reaction was stirred for $15 \mathrm{~min}$ at rt. A saturated aqueous $\mathrm{NaHCO}_{3}$ solution was added until effervescence ceased and then the $\mathrm{MeOH}$ was removed in vacuo to leave only an aqueous medium. The aqueous layer was extracted with ethyl acetate $(3 \times 70 \mathrm{~mL})$. The organic layers were combined, dried over anhydrous $\mathrm{MgSO}_{4}$, filtered, and concentrated under reduced pressure. The residue was then treated with an ethanolic solution of ${ }^{\mathrm{t}} \mathrm{BuOK}(10.4 \mathrm{~g}, 92.69 \mathrm{mmol})$ with vigorous stirring for 20 min at rt. The reaction was then quenched with the addition of a saturated aqueous $\mathrm{NH}_{4} \mathrm{Cl}$ solution (30 $\mathrm{mL}$ ). Ethyl acetate $(100 \mathrm{~mL})$ was added and the resulting upper organic layer was removed, dried over anhydrous $\mathrm{MgSO}_{4}$, filtered, and concentrated in vacuo. Column chromatography ( $10 \%$ ethyl acetate-hexane) of the residue eventually afforded 12 as a yellow solid $(4.37 \mathrm{~g}, 75 \%) . \mathrm{mp} \mathrm{128-130}{ }^{\circ} \mathrm{C}$. IR (solid, $v_{\max } \mathrm{cm}^{-1}$ ): 3243,1685 . ${ }^{1} \mathrm{H}$ NMR $\left(300 \mathrm{MHz}, \mathrm{CDCl}_{3}\right): \delta(\mathrm{ppm}) 7.05(1 \mathrm{H}, \mathrm{br} \mathrm{s}), 6.50(1 \mathrm{H}, \mathrm{br} \mathrm{s}), 5.95(1 \mathrm{H}, \mathrm{br} \mathrm{s}), 5.75(1 \mathrm{H}, \mathrm{s}), 5.21(1 \mathrm{H}, \mathrm{s}), 5.15$ $(1 \mathrm{H}, \mathrm{s}), 4.39(2 \mathrm{H}, \mathrm{q}, J \mathrm{~J} .1), 3.89(3 \mathrm{H}, \mathrm{s}), 3.81(6 \mathrm{H}, \mathrm{s}), 3.41(2 \mathrm{H}, \mathrm{br} \mathrm{s}), 1.36(3 \mathrm{H}, \mathrm{t}, J \mathrm{~J} .1) .{ }^{13} \mathrm{C} \mathrm{NMR}\left(75 \mathrm{MHz}^{\mathrm{CDCl}} \mathrm{CD}_{3}\right.$ : $\delta$ (ppm) 168.6, 158.7, 157.4, 147.5, 145.4, 135.4, 129.5, 124.7, 116.9, 115.1, 99.4, 92.9, 63.9, 61.3, 56.0, 55.3, 52.2, 32.7, 14.3. HRMS (ESI) $\mathrm{m} / z$ calcd for $\mathrm{C}_{19} \mathrm{H}_{23} \mathrm{O}_{6}(\mathrm{M}+\mathrm{H})^{+} 347.1493$, found 347.1493. ${ }^{15}$

Ethyl-3-allyl-4-(benzyloxy)-1,6,8-trimethoxy-2-naphthoate (13). To a solution of the phenol 12 (1.70 g, 4.40 $\mathrm{mmol})$ in acetone $(60 \mathrm{~mL})$ was added benzyl bromide $(0.78 \mathrm{~mL}, 6.60 \mathrm{mmol})$ and $\mathrm{K}_{2} \mathrm{CO}_{3}(911 \mathrm{mg}, 6.60 \mathrm{mmol})$. The mixture was heated at reflux under $\mathrm{N}_{2}$ for $18 \mathrm{~h}$. After cooling to $\mathrm{rt}$, the mixture was filtered through Celite and the filtrate concentrated in vacuo. The resultant residue was purified by silica gel column chromatography ( $7 \%$ ethyl acetate-hexane) to afford the product 13 as a pale liquid $\left(1.82 \mathrm{~g}, 95 \%\right.$ ). IR (liquid, $v_{\max } \mathrm{cm}^{-1}$ ): 2937 , $1721,1618,1580,1342 .{ }^{1} \mathrm{H}$ NMR $\left(300 \mathrm{MHz} \mathrm{CDCl}_{3}\right): \delta(\mathrm{ppm}) 7.56-7.37(5 \mathrm{H}, \mathrm{m}), 7.00(1 \mathrm{H}, \mathrm{d}, J 2.2), 6.53(1 \mathrm{H}, \mathrm{d}, J$ 2.2), 6.07-5.94 (1H, m), 5.12-5.04 (2H, m), $4.97(2 \mathrm{H}, \mathrm{s}), 4.41(2 \mathrm{H}, \mathrm{q}, J 7.1), 3.96(3 \mathrm{H}, \mathrm{s}), 3.88(3 \mathrm{H}, \mathrm{s}), 3.78(3 \mathrm{H}, \mathrm{s})$, $3.65(1 \mathrm{H}, \mathrm{t}, J 1.5), 3.63(1 \mathrm{H}, \mathrm{t}, J 1.5), 1.41(3 \mathrm{H}, \mathrm{t}, J 7.1) .{ }^{13} \mathrm{C} \mathrm{NMR}\left(75 \mathrm{MHz}, \mathrm{CDCl}_{3}\right): \delta(\mathrm{ppm})$ 168.1, 159.3, 157.9, 150.6, 148.3, 137.6, 136.3, 132.9, 128.7 (× 2), 128.1, 127.7 (× 2), 126.9, 125.1, 116.0, 115.4, 99.3, 93.6, 75.9, 63.9, 61.2, 56.1, 55.2, 32.0, 14.3. HRMS (ESI) $\mathrm{m} / z$ calcd for $\mathrm{C}_{26} \mathrm{H}_{29} \mathrm{O}_{6}(\mathrm{M}+\mathrm{H})^{+}$437.1968, found 437.1968.

Ethyl-4-(benzyloxy)-1,6,8-trimethoxy-3-(4-oxopent-2-enyl)-2-naphthoate (14). To a solution of 13 (100 mg, $0.23 \mathrm{mmol})$ in anhydrous, degassed $\mathrm{CH}_{2} \mathrm{Cl}_{2}(10 \mathrm{~mL})$, methyl vinyl ketone $(0.03 \mathrm{~mL}, 0.34 \mathrm{mmol})$ was added as well as the Grubbs II catalyst $(3.9 \mathrm{mg}, 0.005 \mathrm{mmol})$. The reaction mixture was then refluxed for $15 \mathrm{~min}$. Following removal of the solvent, the crude mass obtained was purified by silica gel column chromatography (40\% ethyl acetate-hexane) to afford the $\alpha, \beta$-unsaturated carbonyl compound 14 (77 $\mathrm{mg}, 70 \%)$ as a white solid. $\mathrm{mp} 91-93{ }^{\circ} \mathrm{C}$. IR (solid, $\left.v_{\max } \mathrm{cm}^{-1}\right): 1728,1670,1658 .{ }^{1} \mathrm{H} \mathrm{NMR}\left(300 \mathrm{MHz} \mathrm{CDCl}_{3}\right): \delta(\mathrm{ppm}) 7.50-7.36(5 \mathrm{H}$, m), $6.96(1 \mathrm{H}, \mathrm{d}, J 2.3), 6.92-6.80(1 \mathrm{H}, \mathrm{m}), 6.54(1 \mathrm{H}, \mathrm{d}, J 2.3), 6.05-6.00(1 \mathrm{H}, \mathrm{m}), 4.94(2 \mathrm{H}, \mathrm{s}), 4.36(2 \mathrm{H}, \mathrm{q}, J 7.1)$, 3.96, $(3 \mathrm{H}, \mathrm{s}), 3.86(3 \mathrm{H}, \mathrm{s}), 3.77(3 \mathrm{H}, \mathrm{s}), 3.71(1 \mathrm{H}, \mathrm{d}, J 1.6), 3.69(1 \mathrm{H}, \mathrm{d}, J 1.7), 2.17(3 \mathrm{H}, \mathrm{s}), 1.36(3 \mathrm{H}, \mathrm{t}, J 7.1) .{ }^{13} \mathrm{C}$ NMR $\left(75 \mathrm{MHz}_{\mathrm{CDCl}}\right): \delta$ (ppm) 198.4, 167.9, 159.6, 158.0, 150.95, 148.5, 145.4, 137.2, 132.8, 132.2, 128.8, 128.3, 127.6, 124.8, 124.7, 115.8, 99.6, 93.6, 77.3, 76.1, 63.9, 61.3, 56.2, 55.2, 52.2, 30.8, 26.8, 14.3. HRMS (ESI) $\mathrm{m} / \mathrm{z}$ calcd for $\mathrm{C}_{28} \mathrm{H}_{31} \mathrm{O}_{7}(\mathrm{M}+\mathrm{H})^{+} 479.2072$, found 479.2072 .

5-(Benzyloxy)-7,9,10-trimethoxy-3-(2-oxopropyl)-3,4-dihydro-1H-benzo[g]isochromen-1-one (15). To a solution of the $\alpha, \beta$-unsaturated carbonyl compound $14(480 \mathrm{mg}, 1.00 \mathrm{mmol})$ in $\mathrm{CH}_{2} \mathrm{Cl}_{2}(20 \mathrm{~mL})$ was added $\mathrm{BF}_{3} \cdot \mathrm{OEt}_{2}(1.85 \mathrm{~mL}, 15.00 \mathrm{mmol})$ at $0{ }^{\circ} \mathrm{C}$. The reaction mixture was stirred for $1 \mathrm{~h}$ and then quenched with saturated aqueous $\mathrm{NaHCO}_{3}$ solution $(6 \mathrm{~mL})$. The organic layer was separated and the aqueous part was extracted with $\mathrm{CH}_{2} \mathrm{Cl}_{2}(3 \times 15 \mathrm{~mL})$. The combined organic layers were dried over anhydrous $\mathrm{MgSO}_{4}$, 
concentrated in vacuo, and the residue was purified by silica gel column chromatography (50\% ethyl acetatehexane) to afford $15(290 \mathrm{mg}, 64 \%)$ as a viscous liquid. IR (liquid, $\left.\mathrm{v}_{\max } \mathrm{cm}^{-1}\right): 1715 .{ }^{1} \mathrm{H} \mathrm{NMR}\left(300 \mathrm{MHz} \mathrm{CDCl}_{3}\right): \delta$ (ppm) 7.44-7.37 (5H, m), $6.93(1 \mathrm{H}, \mathrm{d}, J$ 2.0), $6.52(1 \mathrm{H}, \mathrm{d}, J 2.0), 4.96(1 \mathrm{H}, \mathrm{d}, J$ 11.3), $4.89(1 \mathrm{H}, \mathrm{d}, J 11.3), 4.80-$ $4.72(1 \mathrm{H}, \mathrm{m}), 3.96(3 \mathrm{H}, \mathrm{s}), 3.95(3 \mathrm{H}, \mathrm{s}), 3.80(3 \mathrm{H}, \mathrm{s}), 3.27(1 \mathrm{H}, \mathrm{dd}, J 15.90,2.58), 3.02(1 \mathrm{H}, \mathrm{dd}, J 17.01,6.38)$, 2.73-2.63 (2H, m), $2.21(3 \mathrm{H}, \mathrm{s}) .{ }^{13} \mathrm{C} \mathrm{NMR}\left(75 \mathrm{MHz}, \mathrm{CDCl}_{3}\right): \delta(\mathrm{ppm})$ 204.9, 162.2, 161.1, 159.8, 168.6, 145.3, $136.9,135.4,128.7$ ( × 2), 128.5, 128.2 (× 2), 127.2, 116.7, 112.6, 99.7, 93.3, 75.8, 73.1, 63.4, 56.4, 55.3, 48.0, 30.9, 28.9. HRMS (ESI) $\mathrm{m} / \mathrm{z}$ calcd for $\mathrm{C}_{26} \mathrm{H}_{27} \mathrm{O}_{7}(\mathrm{M}+\mathrm{H})^{+} 451.1761$, found 451.1761 .

1-[10-(Benzyloxy)-1-hydroxy-6,8,9-trimethoxyanthracen-2-yl]ethanone (16). The $\alpha, \beta$-unsaturated carbonyl compound 15 (200 mg, $0.46 \mathrm{mmol}$ ) was treated with $10 \%$ aqueous ethanolic $\mathrm{KOH}$ solution ( $3 \mathrm{~mL}$ ) for $1 \mathrm{~h} \mathrm{under}$ refluxing conditions. After complete disappearance of the starting material as monitored by TLC, the reaction mixture was cooled down to $\mathrm{rt}$ and the solution was extracted with ethyl acetate $(3 \times 10 \mathrm{~mL})$. The organic layers were then combined, dried over anhydrous $\mathrm{MgSO}_{4}$ and concentrated under reduced pressure. The crude material was purified by silica gel column chromatography ( $5 \%$ ethyl acetate-hexane) to obtain a yellow solid following evaporation of the eluent, 16 (40 mg, 20\%). $\mathrm{mp} 140-142{ }^{\circ} \mathrm{C}$. IR (liquid, $v_{\max } \mathrm{cm}^{-1}$ ): 3403,1715 ,

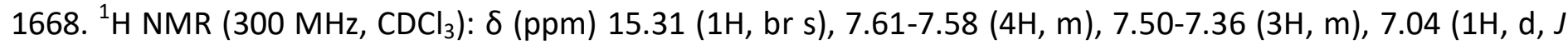
2.2), $6.49(1 \mathrm{H}, \mathrm{d}, J \mathrm{2} .2), 5.08(2 \mathrm{H}, \mathrm{s}), 4.02(3 \mathrm{H}, \mathrm{s}), 4.00(3 \mathrm{H}, \mathrm{s}), 3.84(3 \mathrm{H}, \mathrm{s}), 2.70(3 \mathrm{H}, \mathrm{s}) .{ }^{13} \mathrm{C} \mathrm{NMR}(75 \mathrm{MHz}$, $\left.\mathrm{CDCl}_{3}\right): \delta(\mathrm{ppm}) 202.8,167.2,159.8,159.3,155.8,144.8,137.6,131.9,129.1,128.8(\times 2), 128.3,127.9(\times 2)$, 125.0, 116.2, 115.9, 111.96, 111.8, 99.4, 91.6, 76.3, 63.9, 56.4, 55.3, 27.2. HRMS (ESI) $\mathrm{m} / z$ calcd for $\mathrm{C}_{26} \mathrm{H}_{25} \mathrm{O}_{6}$ $(\mathrm{M}+\mathrm{H})^{+} 433.1648$, found 433.1648 .

\section{5-(Benzyloxy)-7,9,10-trimethoxy-3-(2-methyl-1,3-dithiolan-2-yl)methyl-3,4-dihydro-1H-benzo[g]-} isochromen-1-one (17) and 5-(benzyloxy)-10-hydroxy-7,9-dimethoxy-3-(2-methyl-1,3-dithiolan-2-yl)methyl3,4-dihydro-1H-benzo[g]isochromen-1-one (17a). To a solution of the lactone 15 (280 $\mathrm{mg}, 0.62 \mathrm{mmol})$ in toluene $(20 \mathrm{~mL})$ was added ethanedithiol $(0.10 \mathrm{~mL}, 1.24 \mathrm{mmol})$ followed by the addition of $p$-toluenesulfonic acid monohydrate $(5 \mathrm{mg})$. The solution was heated to reflux for $18 \mathrm{~h}$, cooled down to rt, and extracted with ethyl acetate $(3 \times 10 \mathrm{~mL})$. The organic layers were combined, dried over anhydrous $\mathrm{MgSO}_{4}$, concentrated in vacuo, and the crude product was purified by column chromatography to afford 17 as a solid white product (220 mg, 70\%) along with a minor viscous liquid 17a (50 mg, 16\%) following evaporation of the eluent. 17: $\mathrm{mp}$ 168-170 ${ }^{\circ} \mathrm{C}$. IR (solid, $\left.v_{\max } \mathrm{cm}^{-1}\right): 1711 .{ }^{1} \mathrm{H}$ NMR $\left(300 \mathrm{MHz}, \mathrm{CDCl}_{3}\right): \delta(\mathrm{ppm})$ 7.47-7.37 (5H, m), $6.96(1 \mathrm{H}, \mathrm{d}, J 2.3)$, $6.52(1 \mathrm{H}, \mathrm{d}, J 2.3), 4.97(1 \mathrm{H}, \mathrm{d}, J 11.3), 4.91(1 \mathrm{H}, \mathrm{d}, J 11.3), 4.63-4.57(1 \mathrm{H}, \mathrm{m}), 3.97(3 \mathrm{H}, \mathrm{s}), 3.96(3 \mathrm{H}, \mathrm{s}), 3.82(3 \mathrm{H}$, s), 3.37-3.26 (5H, m), $2.78(1 \mathrm{H}, \mathrm{dd}, J 15.9,10.4), 2.52(1 \mathrm{H}, \mathrm{dd}, J 15.0,6.9), 2.24(1 \mathrm{H}, \mathrm{dd}, J 15.0,3.7), 1.90(3 \mathrm{H}, \mathrm{s})$. ${ }^{13} \mathrm{C} \mathrm{NMR}\left(75 \mathrm{MHz}, \mathrm{CDCl}_{3}\right): \delta$ (ppm) 162.3, 161.0, 159.7, 158.4, 145.3, 136.9, 135.3, $128.8(\times 2), 128.5,128.2(\times$ 2), 127.4, 116.7, 112.95, 99.7, 93.2, 76.3, 75.9, 64.7, 63.4, 56.4, 55.3, 49.8, 39.9, 39.8, 32.9, 30.1. HRMS (ESI) $\mathrm{m} / \mathrm{z}$ calcd for $\mathrm{C}_{28} \mathrm{H}_{31} \mathrm{O}_{6} \mathrm{~S}_{2}(\mathrm{M}+\mathrm{H})^{+}$527.1564, found 527.1564. 17a: IR (liquid, $v_{\max } \mathrm{cm}^{-1}$ ): 1719, 1649, $1607,1558$. ${ }^{1} \mathrm{H}$ NMR (300 MHz, CDCl$): \delta(p p m) 12.99(1 \mathrm{H}, \mathrm{s}), 7.45-7.37(5 \mathrm{H}, \mathrm{m}), 6.93(1 \mathrm{H}, \mathrm{d}, J 2.3), 6.50(1 \mathrm{H}, \mathrm{d}, J 2.3), 4.90$ $(2 \mathrm{H}, \mathrm{s}), 4.78-4.71(1 \mathrm{H}, \mathrm{m}), 3.99(3 \mathrm{H}, \mathrm{s}), 3.83(3 \mathrm{H}, \mathrm{s}), 3.41-3.27(5 \mathrm{H}, \mathrm{m}), 2.73(1 \mathrm{H}, \mathrm{dd}, J 16.3,10.6), 2.53(1 \mathrm{H}, \mathrm{dd}, J$ 15.1, 7.1), $2.26(1 \mathrm{H}, \mathrm{dd}, J 15.1,3.6), 1.89(3 \mathrm{H}, \mathrm{s}) .{ }^{13} \mathrm{C} \mathrm{NMR}\left(75 \mathrm{MHz}, \mathrm{CDCl}_{3}\right): \delta(\mathrm{ppm}) 170.6,162.2,161.2,161.0$, 141.0, 137.0, 136.6, 128.7 (× 2), 128.5, 128.3 (× 2), 124.7, 111.4, 99.6, 98.7, 93.7, 77.8, 75.6, 64.6, 56.3, 55.4, 49.9, 39.92 ( $\times 2), 32.94,28.9$. HRMS (ESI) $\mathrm{m} / z$ calcd for $\mathrm{C}_{27} \mathrm{H}_{29} \mathrm{O}_{6} \mathrm{~S}_{2}(\mathrm{M}+\mathrm{H})^{+}$513.1407, found 513.1407. Crystal data for 17, assigned CCDC no. $1030317, \mathrm{C}_{28} \mathrm{H}_{30} \mathrm{O}_{6} \mathrm{~S}_{2}: \mathrm{M}_{r} 526.64$ g.mol ${ }^{-1}$; crystal dimensions (mm) $0.31 \times 0.16 \times$ 0.07; crystal system, monoclinic; space group, $P 2_{1} / c$; unit cell dimensions and volume, $a=9.3246(2) \AA, b=$ 21.4592(5) $\AA, c=12.9652(3) \AA, \alpha=90^{\circ}, \beta=101.039(1)^{\circ}, \gamma=90^{\circ}, V=2546.3(1) \AA^{3}, Z=4$; calculated density $r_{\text {calcd }}$ $1.374 \mathrm{Mg} / \mathrm{m}^{3}$; linear absorption coefficient, $\mu=0.129 \mathrm{~mm}^{-1}$; radiation and wavelength, $\operatorname{MoK} \alpha_{1}=0.71073 \AA$; temperature of measurement, $173(2) \mathrm{K}, 2 \theta_{\max } 28.00^{\circ}$; 31024 reflections measured, 6106 unique reflections, 
4962 observed reflections $[I>2 \sigma(I)] ; \mathrm{R}_{\text {int }}=0.0256 ; \mathrm{R}_{1}[I>2.0 \sigma(I)]=0.0463, \mathrm{wR} 2[\mathrm{all}]=0.1287, \mathrm{GoF}=1.039$, refined on $F^{2}$; residual electron density, 1.055 and -0.484 e $\AA^{-3}$.

5-Hydroxy-7,9-dimethoxy-3-propyl-3,4-dihydro-1H-benzo[g]isochromen-1-one (18). To a solution of 17 (200 $\mathrm{mg}, 0.38 \mathrm{mmol})$ in EtOH $(50 \mathrm{~mL})$, was added Raney nickel $\left(5.0 \mathrm{~g}, 50 \%\right.$ slurry in $\left.\mathrm{H}_{2} \mathrm{O}\right)$. The heterogeneous mixture was heated to reflux for $72 \mathrm{~h}$ and then gravity filtered through filter paper to remove the solid. The solvent was then removed under reduced pressure to give 18 (95 mg, 79\%) as a white solid. $\mathrm{mp} 161-163{ }^{\circ} \mathrm{C}$. IR (solid, $\left.v_{\max } \mathrm{cm}^{-1}\right): 3216,1691 .{ }^{1} \mathrm{H}$ NMR $\left(300 \mathrm{MHz} \mathrm{CDCl}_{3}\right): \delta(\mathrm{ppm}) 8.65(1 \mathrm{H}, \mathrm{s}), 6.93(1 \mathrm{H}, \mathrm{d}, J 1.9), 6.47(1 \mathrm{H}, \mathrm{d}, J$ 1.9), 4.55-4.46 (1H, m), $3.94(3 \mathrm{H}, \mathrm{s}), 3.94(3 \mathrm{H}, \mathrm{s}), 3.18(1 \mathrm{H}, \mathrm{dd}, J 16.1,3.1), 2.82(1 \mathrm{H}, \mathrm{dd}, J$ 16.1, 11.2), 1.89-1.82 $(1 \mathrm{H}, \mathrm{m}), 1.76-1.62(2 \mathrm{H}, \mathrm{m}), 1.61-1.46(2 \mathrm{H}, \mathrm{m}), 0.95(3 \mathrm{H}, \mathrm{t}, J 7.3) .{ }^{13} \mathrm{C} \mathrm{NMR}\left(75 \mathrm{MHz}, \mathrm{CDCl}_{3}\right): \delta(\mathrm{ppm}) 166.8$, $160.9,158.2,145.8,129.2,121.1,119.8,119.5,118.5,98.2,91.5,78.1,55.7,55.6,37.3,27.5,18.3$, 13.9. HRMS (ESI) $\mathrm{m} / z$ calcd for $\mathrm{C}_{18} \mathrm{H}_{21} \mathrm{O}_{5}(\mathrm{M}+\mathrm{H})^{+} 317.1390$, found 317.1390 .

7,9-dimethoxy-3-propyl-3,4-dihydro-1H-benzo[g]isochromen-1,5,10-trione (10). Naphthalene 18 (40 mg, $0.12 \mathrm{mmol}$ ) was dissolved in $\mathrm{CH}_{3} \mathrm{CN}(2 \mathrm{~mL})$ and ceric ammonium nitrate (CAN) (131 $\left.\mathrm{mg}, 0.24 \mathrm{mmol}\right)$ in $\mathrm{H}_{2} \mathrm{O}(1$ $\mathrm{mL}$ ) was added dropwise at $0{ }^{\circ} \mathrm{C}$. The reaction mixture was stirred for $30 \mathrm{~min}$, followed by the addition of $\mathrm{H}_{2} \mathrm{O}$ $(2 \mathrm{~mL})$ and ethyl acetate $(10 \mathrm{~mL})$. The organic layer was separated, dried over anhydrous $\mathrm{MgSO}_{4}$, filtered and the filtrate was then concentrated in vacuo. The residue was purified by silica gel column chromatography (10\% ethyl acetate-hexane) to afford the quinone $10(30.5 \mathrm{mg}, 80 \%)$ as an orange solid. $\mathrm{mp} 107-108{ }^{\circ} \mathrm{C}$. IR (solid, $\left.v_{\max } \mathrm{cm}^{-1}\right): 1734 \mathrm{~cm}^{-1} .{ }^{1} \mathrm{H}$ NMR $\left(300 \mathrm{MHz}, \mathrm{CDCl}_{3}\right): \delta(\mathrm{ppm}) 7.08(1 \mathrm{H}, \mathrm{d}, J 2.1), 6.69(1 \mathrm{H}, \mathrm{d}, J 1.1), 4.49-4.39$ $(1 \mathrm{H}, \mathrm{m}), 3.89(3 \mathrm{H}, \mathrm{s}), 3.88(3 \mathrm{H}, \mathrm{s}), 3.04(1 \mathrm{H}, \mathrm{dd}, J$ 18.7, 2.9), $2.44(1 \mathrm{H}, \mathrm{dd}, J 18.7,11.9), 1.86-1.77(1 \mathrm{H}, \mathrm{m}), 1.72-$ $1.63(1 \mathrm{H}, \mathrm{m}), 1.59-1.43(2 \mathrm{H}, \mathrm{m}), 0.95(3 \mathrm{H}, \mathrm{t}, J 7.3) .{ }^{13} \mathrm{C} \mathrm{NMR}\left(75 \mathrm{MHz}, \mathrm{CDCl}_{3}\right): \delta(\mathrm{ppm}) 184.1,177.9,164.6$, 162.0, 160.3, 147.7, 134.9, 130.7, 114.8, 105.1, 103.3, 77.3, 56.5, 56.0, 36.6, 26.9, 18.0, 13.8. HRMS (ESI) $\mathrm{m} / \mathrm{z}$ calcd for $\mathrm{C}_{18} \mathrm{H}_{19} \mathrm{O}_{6}(\mathrm{M}+\mathrm{H})^{+} 331.1187$, found 331.1187 .

\section{Acknowledgements}

This research was supported by the National Research Foundation (NRF, GUN 2053652 and IRDP of the NRF (South Africa) and by the University of the Witwatersrand (Science Faculty Research Council). We also gratefully acknowledge the University of the Witwatersrand for a postdoctoral Fellowship to MFH. Mr B Moolman and Dr M Stander from the MS service at the University of Stellenbosch are thanked for recording the HRMS.

\section{Supplementary Material}

Copies of ${ }^{1} \mathrm{H}$ NMR and ${ }^{13} \mathrm{C}$ NMR spectra presented in the Supplementary Material are available in the online version.

\section{References}

"IIIFor queries regarding X-ray crystallography, contact Andreas.Lemmerer@wits.ac.za

1. Donner, C. D. Nat. Prod. Rep. 2015, 32, 578-604. 
https://doi.org/10.1039/C4NP00127C.

2. (a) Parisot, D.; Devys, M.; Férézou, J.-P.; Barbier, M. Phytochem. 1983, 22, 1301-1303. https://doi.org/10.1016/0031-9422(83)80253-2.

(b) Tatum, J. H.; Baker, R. A.; Berry, R. E. Phytochem. 1989, 28, 283-284. https://doi.org/10.1016/0031-9422(89)85062-9.

3. Kitagawa, R. R.; Raddi, M. S. G.; dos Santos, L. C.; Vilegas, W. Chem. Pharm. Bull. 2004, 52, 1487-1488.

4. Devienne, K. F.; Raddi, M. S. G.; Varanda, E. A.; Vilegas, W. Z. Naturforsch. C 2002, 57, 85-88.

5. Varanda, E. A.; Raddi, M. S. G.; de Luz Dias, F.; Araújo, M. C. P.; Gibran, S. C. A.; Takahashi, C. S.; Vilegas, W. Teratogenesis, Carcinogenesis, and Mutagenesis 1997, 17, 85-95.

https://doi.org/10.1002/(SICI)1520-6866(1997)17:2<85::AID-TCM4>3.0.CO;2-A.

6. Wood and Tree Fungi: Biology, Damage, Protection, and Use, Schmidt, O. Springer-Verlag Berlin Heidelberg 2006, Chapter 4, p. 120, ISBN-10 3-540-32138-1.

7. Blackburn, G. M.; Ekong, D. E. U.; Neilson, A. H.; Todd, L. Chimia 1965, 19, 208-212.

8. Edwards, R. L.; Kale, N. Tetrahedron 1965, 21, 2095-2107. https://doi.org/10.1016/S0040-4020(01)98346-2.

9. Saikawa, Y.; Watanabe, T.; Hashimoto, K.; Nakata, M. Phytochem. 2000, 55, 237-240. https://doi.org/10.1016/S0031-9422(00)00282-X.

10. Giesbers, G., Van Schenck, J.; Gutierrez, S. M. V.; Robinson, S. C.; Ostroverkhova, O. ACS Omega, 2019, 4, 13309-13318.d https://doi.org/10.1021/acsomega.9b01490.

11. Giles, R. G. F.; Reuben, M. K.; Roos, G.P. S. Afr. J. Chem. 1979, 32, 127-129.

12. Giles, R. G. F.; Green, I. R.; Hugo, V. I., S. Afr. J. Chem. 1990, 43, $28-33$.

13. Donner, C. D.; Gill, M.; Tewierik, L. M. Molecules 2004, 9, 498-512.

14. Donner, C.; Cuzzupe, A.; Falzon, C.; Gill, M. Tetrahedron, 2012, 68, 2799-2805. https://doi.org/10.1016/i.tet.2012.02.009.

15. Sumani, J. E. Y.; Ngwira, K. J.; Lemmerer A.; de Koning, C. B. Eur. J. Org. Chem. 2019, 1145-1153. https://doi.org/10.1002/ejoc.201801595.

16. (a) Mmutlane, E. M. Michael, J. P.; Green, I. R.; de Koning, C. B. Org. \& Biomol. Chem. 2004, 2, 2461-2470. https://doi.org/10.1039/B407208A.

(b) Pillay, A.; Rousseau, A. L.; Fernandes, M. A.; de Koning, C. B. Org. \& Biomol. Chem. 2012, 10, 7809-7819. https://doi.org/10.1039/C2OB26126J.

17. Lowell, A. N.; Fennie, M. W.; Kozlowski, M. C. J. Org. Chem., 2008, 73, 1911-1918. https://doi.org/10.1021/jo7024114.

18. Anthracene $\mathbf{1 6}$ is presumably formed by abstraction of a benzylic hydrogen of the allyl side chain of $\mathbf{1 5}$ which results in nucleophilic attack at the ester resulting in the formation of the resultant naphthol 16. We were unable to improve the yield of this aromatic ring forming reaction by attempting the transformation under a variety of reaction conditions and different bases.

19. X-ray crystallographic data for compound $\mathbf{1 7}$ is given in the experimental section.

20. Wadsworth, A. D.; Jonathan Sperry, J.; Brimble, M. A. Synthesis, 2010, 2604-2608.

https:// doi.org/10.1055/s-0029-1218832.

21. Bruker, SAINT+, version 6.02 (including XPREP), Bruker AXS Inc., Madison, WI, USA, 1999.

22. Farrugia, L. J. App. Cryst. 1999, 32, 837-838.

23. Sheldrick, G. M. SHELX, release 97-2 (includes SHELXS and SHELXL), University of Göttingen, 1997.

24. Farrugia, L. J. App. Cryst. 1997, 30, 565. 
25. Spek, A. J. App. Cryst. 2003, 36, 7-13.

This paper is an open access article distributed under the terms of the Creative Commons Attribution (CC BY) license (http://creativecommons.org/licenses/by/4.0/) 